\author{
М.I. ГЕРАСИМЮК
}

\title{
СТАТЕВО-ВІКОВА ХАРАКТЕРИСТИКА ТА РЕЗУЛЬТАТИ КЛІНІЧНОГО ОБСТЕЖЕННЯ ХВОРИХ, ЩО ПЕРЕНЕСЛИ ТОНЗИЛЕКТОМІЮ
}

\author{
ДВНЗ «Тернопільський державний медичний університет імені І.Я. Горбачевського МОЗ України», \\ м. Тернопіль, Україна
}

\begin{abstract}
Мета: порівняти рівень захворюваності на хронічний тонзиліт серед чоловіків і жінок працездатного віку та встановити його найчастіші ознаки.

Матеріали і методи. Проведено ретроспективний аналіз 272 карт стаціонарних хворих, які перебували на лікуванні у лОР-відділенні комунального закладу Тернопільської обласної ради «Тернопільська Університетська лікарня» за період з 2014 по 2016 роки з приводу декомпенсованого хронічного тонзиліту.

Результати. Проведено порівняння частоти виникнення хронічного тонзиліту за статевою ознакою та встановлено віковий період найчастішого його розвитку. Проаналізовано частоту різних симптомів захворювання та результати лабораторних досліджень.

Висновки. Найчастіше декомпенсований хронічний тонзиліт реєструється у віковому періоді від 18 до 44 років, причому у жінок у 1,43 разу частіше, ніж у чоловіків. Найхарактернішими симптомами є: щорічні повторні ангіни, біль у горлі з періодичним посиленням, першінням, напади кашлю, гіперемія і набряклість країв дужок мигдаликів, наявність у криптах рідкого, густого казеозного або у вигляді пробок гнійного вмісту. У загальному аналізі крові може відмічатися помірний лейкоцитоз із підвищеним вмістом паличкоядерних нейтрофілів і лімфоцитів та прискорення швидкості осідання еритроцитів. Досить часто реєструється знижений вміст еритроцитів.
\end{abstract}

КЛЮЧОВІ СЛОВА: хронічний тонзиліт, вік, стать, симптоми, лабораторні показники.

Поширеність хронічного тонзиліту (XT) серед лОР-патології продовжує залишатися високою. За даними різних авторів, на ХТ страждають від $12,5 \%$ до 22,1\% населення, що становить від 22\% до 40\% серед усієї хронічної лОР-патології [3;4;7]. Причому, незважаючи на численні дослідження і певні досягнення в розробці та оптимізації лікувально-діагностичного алгоритму, частота хронічної патології мигдаликів за останні роки зросла у 1,5-1,8 разу [1;6]. В Україні цей показник на сьогодні сягає 1260 на 10 тис. населення [2;5].

Мета роботи - порівняти рівень захворюваності на XT серед чоловіків і жінок працездатного віку та встановити його найчастіші ознаки.

Матеріали і методи. Проведено ретроспективний аналіз 272 карт стаціонарних хворих, які перебували на стаціонарному лікуванні у лОРвідділенні комунального закладу Тернопільської обласної ради «Тернопільська Університетська лікарня» за період з 2014 по 2016 роки та перенесли тонзилектомію з приводу декомпенсованого ХT. При госпіталізації у стаціонар усім хворим проводилося стандартне обстеження, яке включало скарги, анамнез захворювання, об'єктивне обстеження орофрарингеальної ділянки, а також проведення лабораторних досліджень (загальний і біохімічний аналіз крові, електрокардіографрія).

(c) М.І. Герасимюк, 2016
Результати дослідження та їх обговорення. Розподіл хворих за віком і статтю наведений у табл. 1, 2. Як видно з табл. 1, жінки хворіють на XT у 1,43 разу частіше, ніж чоловіки. Найчастіше захворювання реєструється у віковому періоді від 18 до 44 років, тобто в осіб працездатного віку, що становить 94,5\% від усіх госпіталізованих пацієнтів (табл. 2). У осіб, старших за 75 років, ХТ майже не реєструвався.

На щорічні повторні скаржилися 246 (90,4\%) хворих, біль у горлі 3 періодичним посиленням чи згасанням, дертям, напади кашлю відмічали 272 (100\%) хворих. Характерним було посилення болю у ранкові часи; хворі також пов'язували біль із прийомом холодної їжі чи рідини, що було відмічено у $246(90,4 \%)$ хворих; періодичне підвищення температури до $37,2-37,4^{\circ} \mathrm{C}$ у періоди загострення тривалістю 4-5 днів зазначали 267 (98,2\%) пацієнтів; зміна відчуття смаку і неприємний запах з рота були у 215 (79,0\%) хворих; постійне почервоніння і валикоподібне потовщення країв піднебінних дужок було у 169 (62,1\%) обстежених; наявність гнійних пробок у лакунах мигдаликів відмічали у 144 (52,9\%) випадках; болючість лімфровузлів, розташованих по передньому краю грудинно-ключично-соскового м'яза, була у 131 (48,2\%) хворого; вестибулярні порушення виникали у 114 (41,9\%) хворих. Супутні захворювання відзначали: ревма- 
Таблиця 1. Розподіл хворих на хронічний тонзиліт за статтю за результатами ретроспективного аналізу історій хвороби (2014-2016 рр.)

\begin{tabular}{|c|c|c|c|c|c|}
\hline Стать & Рік & 18-44 роки & 45-59 років & 60-74 роки & Разом \\
\hline \multirow[t]{3}{*}{ Чоловіки } & 2014 & 43 & - & - & 43 \\
\hline & 2015 & 37 & 2 & - & 39 \\
\hline & 2016 & 29 & 1 & - & 30 \\
\hline \multirow[t]{3}{*}{ Жінки } & 2014 & 40 & 6 & 1 & 47 \\
\hline & 2015 & 66 & 3 & 1 & 70 \\
\hline & 2016 & 42 & 1 & - & 43 \\
\hline \multirow[t]{3}{*}{ Усього } & 2014 & 83 & 6 & 1 & 90 \\
\hline & 2015 & 103 & 5 & 1 & 109 \\
\hline & 2016 & 71 & 2 & - & 73 \\
\hline
\end{tabular}

Таблиця 2. Аналіз вікових груп хворих на хронічний тонзиліт за результатами ретроспективного аналізу історій хвороби (2014-2016 рр.)

\begin{tabular}{|l|c|c|c|c|}
\hline \multicolumn{1}{|c|}{ Стать/вік } & 18-44 роки & 45-59 років & $60-74$ роки & Разом \\
\hline Чоловіки & 109 & 3 & - & 112 \\
\hline Жінки & 148 & 10 & 2 & 160 \\
\hline Усього & 257 & 13 & 2 & 272 \\
\hline
\end{tabular}

тизм - 38 (14,0\%) хворих, ревматоїдний артрит 46 (16,9\%), порушення 3 боку серцево-судинної системи - 137 (50,4\%), проблеми 3 нирками $33(12,1 \%)$, інші супутні захворювання були відмічені у $8(2,9 \%)$ хворих.

При об'єктивному обстеженні виявлялися місцеві ознаки тривалого запалення в мигдаликах. Майже у всіх хворих визначалася гіперемія і набряк країв дужок мигдаликів. Зрощення і спаяність передніх і задніх дужок самого мигдалика відмічено у 182 (66,9\%) хворих. Ознаку Зака (набряклість у ділянці верхнього кута, утвореного передніми і задніми дужками) відмічено у 256 (94,1\%) хворих, ознаку Б.С. Преображенського (гіперплазія та інфрільтрація країв верхніх відділів передніх і задніх дужок) відмічено у $237(87,1 \%)$ хворих, ознаку Гізі (гіперемія передніх дужок) виявили у 269 (98,9\%) хворих. Наявність у криптах мигдаликів рідкого, густого казеозного або у вигляді пробок гнійного вмісту, іноді з неприємним запахом, спостерігалася у 201 (73,9\%) хворого.

При проведенні лабораторних досліджень у загальному клінічному аналізі крові відчутне збільшення кількості лейкоцитів відмічалося лише у 8 (2,9\%) хворих, збільшення кількості поличкоядерних нейтрофрілів до 8-16\% - у 84 (30,9\%) хворих при одночасному зниженні сегментоядерних нейтрофрілів до рівня, меншого за 50\%, -у 65 (23,9\%) хворих. Лімфоцитоз з питомою часткою лімфроцитів, більшою за 37\%, зареєстрований у 33 (12,1\%) хворих, підвищення ШОЕ до 20-35 мм/год. - у 25 (9,2\%), анемія - у $80(29,4 \%)$ хворих. У біохімічному аналізі крові диспротеїнемія відмічалася у $36(13,2 \%)$ хворих.
На ЕКГ-дослідженні ті чи інші відхилення від прийнятої норми були відмічені у 88,6\% (241) хворих. Ревмопроби були позитивними у 16,5\% (45) хворих.

\section{Висновки}

Таким чином, результати проведеного дослідження свідчать, що жінки хворіють на ХТ частіше, ніж чоловіки. Захворювання реєструється переважно у віковому періоді від 18 до 44 років. Найбільш частими суб'єктивними симптомами були: скарги на щорічні повторні ангіни, біль у горлі 3 періодичним посиленням чи згасанням, з посиленням у ранкові часи, а також у зв'язку із прийомом холодної їжі чи рідини, першіння, напади кашлю, періодичне підвищення температури у періоди загострення. Об'єктивно при фрарингоскопії найчастіше визначалися: гіперемія і набряклість країв дужок мигдаликів, наявність у криптах рідкого, густого казеозного або у вигляді пробок гнійного вмісту, нерідко з неприємним запахом.

Із лабораторних методів обстеження у загальному аналізі крові досить часто реєструвалася анемія, причому у жінок вона відмічалася утричі частіше, ніж у чоловіків. Непостійним був помірний лейкоцитоз із підвищеним вмістом паличкоядерних нейтрофрілів і лімфроцитів та підвищення реакції осідання еритроцитів. Підвищений вміст лімфроцитів також частіше реєструвався у жінок, ніж у чоловіків.

\section{Висновки}

1. Найчастіше декомпенсований ХТ реєструється у віковому періоді від 18 до 44 років, причому у жінок у 1,43 разу частіше, ніж у чоловіків.

2. Найхарактернішими симптомами при декомпенсованому хронічному тонзиліті є: щорічні по- 
вторні ангіни, біль у горлі з періодичним посиленням, першіння, напади кашлю, гіперемія і набряклість країв дужок мигдаликів, наявність у криптах рідкого, густого казеозного або у вигляді пробок гнійного вмісту.

3. У загальному аналізі крові у хворих на декомпенсований хронічний тонзиліт може відмічатися помірний лейкоцитоз із підвищеним вмістом паличкоядерних нейтрофілів і лімфоцитів та прискорення швидкості осідання еритроцитів. Досить часто реєструється знижений вміст еритроцитів.

Перспективи подальших досліджень. Проведення подальших досліджень дозволить удосконалити алгоритми діагностики ХТ і тактику його лікування.

\section{Список літератури}

1. Крючко Т. А. Проблема тонзиллита в педиатрической практике / Т. А. Крючко, О. Я. Ткаченко, Т. В. Шпехт // Совр. педиатрия. - 2012. - № 2 (42). - С. 41-46.

Попович В. І. Хронічний тонзиліт та поєднані з ним соматичні захворювання / В. І. Попович // Природная медицина. 2014. - № 1. - С. 74-82.

3. Приступа И. В. Использование гомеопатических препаратов в комплекном лечении хронических тонзиллитов / И. В. Приступа, Н. А. Чухольская, Ю. В. Сятковская // Журнал вушних, носових і горлових хвороб. - 2013. - № 3. - С. 230-231.

4. Селезнев К. Г. Перитонзиллярный абсцесс - нужна ли тонзиллэктомия? (матеріали щорічної традиційної осінньої конфреренції Українського наукового медичного товариства оториноларингологів «Нові технології в оториноларингології») / К. Г. Селезнев, П. В. Андреев, А. В. Харьковский // Журнал вушних, носових і горлових хвороб. - 2012. - № 5. - С. 131-132.

5. Цимар А. В. Порівняльна характеристика консервативного та хірургічного лікування хворих з хронічним тонзилітом в залежності від стадії захворювання / А. В. Цимар, О. В. Чорній // XII з'їзд оториноларингологів України, Львів, 18-20 трав. 2015 р. - Львів, 2015. - С. 155.

6. Чистякова В. Р. Ангина и хронический тонзиллит (аналитический обзор) / В. Р. Чистякова // Вестник отоларангол. 2012. - № 1. - C. 68-76.

7. Features of the dynamics parameters of cellular immunity and the level of some cytokines in children with chronic tonsillitis / O. I. Smiyan, I. A. Mozgova, O. H. Vasyliyeva [et al.] // Scientific enquiry in the contemporary world: theoretical basics and innovative approach. - 2014. - Vol. 1. Natural sciences. - P. 80-84.

\section{References}

1. Kryuchko, T.A., Tkachenko, O.Ya. \& Shpekht T.V. (2012). Problema tonzyllita v pediatrycheskoy praktike [The problem of tonsillitis in pediatric practice]. Sovremennaya pediatriya - The Modern Pediatric, 2 (42), 41-46 [in Ukrainian].

2. Popovych, V.I. (2014). Khronichnyi tonzylit ta poyednani z nym somatychni zakhvoryuvannya [The chronic tonsillitis and its combined somatic diseases]. Pryrodnaya medytsyna - The natural Medicine, 1, 74-82 [in Ukrainian].

3. Pristupa, I.V., Chuholskaya, N.A. \& Syatkovskaya Yu. V. (2013). Ispolzovanye gomeopatycheskykh preparatov v kompleknom lechenii khronycheskikh tonzyllitov [The applying of the homeopathic medicines in complex treatment of the chronic tonsillitis]. Zhurnal vushnykh, nosovykh i horlovykh khvorob - Journal of Ear, Nose and Throat Diseases, 3, 230231 [in Ukrainian].

4. Seleznev, K.H., Andreev, P.V. \& Kharkivskyy, A.V. (2012) Perytonzyllyarnyi abstsess - nuzhna li tonzylléktomiya? [The peritonsillar abscess - whether tonsillectomy is needed?]. Materialy shchorichnoi tradytsiynoi osinnoi konferentsii Ukrainskoho naukovoho medychnoho tovarystva otorynolarynholohiv «Novi tekhnolohii v otorynolarynholohii» [The materials of annual traditional autumn Ukrainian scientific medical ENT-specialists society conference «The new technologies in ENT»]. Zhurnal vushnykh, nosovykh i horlovykh khvorob - Journal of Ear, Nose and Throat Diseases, 5, 131-132 [in Ukrainian].

5. Tsymar, A.V. \& Chorniy, O.V. (2015, 18-20 may). Porivnyalna kharakterystyka konservatyvnoho ta khirurhichnoho likuvannya khvorykh z khronichnym tonzylitom $v$ zalezhnosti vid stadii zakhvoryuvannya [The comparative characteristic of conservative and surgical treatment of patients with chronic tonsillitis depending on the disease stage]. Proceedings of the 12rd Congress: XII zyizd otorynolarynholohiv Ukrainy - XII meeting of Ukrainian ENT-specialists. Lviv, p. 155 [in Ukrainian].

6. Chystyakova V.R. (2012). Angina i khronicheskiy tonzyllit (analiticheskiy obzor) [Acute and chronic tonsillitis (Analytic review)]. Vestnyk otolarangol. - Bulletin of Otorhinolaryngology, 1, 68-76 [in Ukrainian].

7. Smiyan, O.I., Mozgova, I.A. \& Vasyliyeva, O.H. (2014). Features of the dynamics parameters of cellular immunity and the level of some cytokines in children with chronic tonsillitis. Scientific enquiry in the contemporary world: theoretical basics and innovative approach. Natural sciences, 1, 80-84 [in Ukrainian]. 
ПОЛОВО-ВОЗРАСТНАЯ ХАРАКТЕРИСТИКА И РЕЗУЛЬТАТЫ КЛИНИЧЕСКОГО ОБСЛЕДОВАНИЯ БОЛЬНЫХ, ПЕРЕНЕСШИХ ТОНЗИЛЛЭКТОМИЮ

М.И. Герасимюк

ГВУЗ «Тернопольский государственный медицинский университет имени И.Я. Горбачевского МЗ Украины»,

г. Тернополь, Украина

Цель: сравнить уровень заболеваемости хроническим тонзиллитом среди мужчин и женщин трудоспособного возраста и установить его наиболее частые признаки.

Материалы и методы. Проведен ретроспективный анализ 272 карт стационарных больных, находившихся на лечении в лоР-отделении коммунального учреждения Тернопольского областного совета «Тернопольская Университетская больница» за период с 2014 по 2016 год по поводу декомпенсированного хронического тонзиллита.

Результаты. Проведено сравнение частоты возникновения хронического тонзиллита по половому признаку и установлен возрастной период наиболее частого его развития. Проанализирована частота различных симптомов заболевания и результаты лабораторных исследований.

Выводы. Наиболее часто декомпенсированный хронический тонзиллит регистрируется в возрастном периоде от 18 до 44 лет, причем у женщин в 1,43 раза чаще, чем у мужчин. Характерными симптомами являются: ежегодные повторные ангины, боль в горле с периодическим усилением, першение, приступы кашля, гиперемия и отечность краев дужек миндалин, наличие в криптах жидкого, густого казеозного или в виде пробок гнойного содержимого. В общем анализе крови может отмечаться умеренный лейкоцитоз с повышенным содержанием палочкоядерных нейтрофилов и лимфоцитов и ускорение СОЭ. Достаточно часто регистрируется сниженное содержание эритроцитов.

КЛЮЧЕВЫЕ СЛОВА: хронический тонзиллит, возраст, пол, симптомы, лабораторные показатели.

\section{GENDER AND AGE CHARACTERISTICS AND RESULTS OF CLINICAL EXAMINATION OF PATIENTS WHO UNDERWENT TONSILLECTOMY}

M.I. Herasymyuk

I. Horbachevsky Ternopil State Medical University

Purpose: to compare the morbidity level of chronic tonsillitis among men and women of working age and set its the most common symptoms.

Materials and methods. Was perfomed a retrospective analysis of 272 patients cards with decompensated chronic tonsillitis, who were treated at the ENT department of municipal institutions of Ternopil Regional Council «Ternopil University Hospital» at the period from 2014 to 2016 years.

Results. Was comparison the incidence of chronic tonsillitis by gender and was set the age period of the most frequent development. Was analyzed the frequency of various symptoms and results of laboratory tests.

Conclusions. Mostly decompensated chronic tonsillitis registered in the age period from 18 to 44 years, and its 1.43 times more often in women than men. The most characteristic symptoms of decompensated chronic tonsillitis are: annual recurrent tonsillitis, sore throat with periodic amplification, scratchy, fits of coughing, redness and swelling of the tonsils edges of brackets, the presence of liquid, thick or as caseous pus plugs in crypts. In general blood investigation the moderate leukocytosis with a high content of band neutrophils and lymphocytes and acceleration of erythrocyte sedimentation rate can be found. Quite often low content of red blood cells can be recorded.

KEY WORDS: chronic tonsillitis, age, sex, symptoms, laboratory parameters.

Рукопис надійшов до редакції 17.12.2016 p.

\section{Відомості про автора:}

Герасимюк Максим Ілліч - аспірант кафедри оториноларингології з офтальмологією і нейрохірургією ДВНЗ «Тернопільський державний медичний університет імені І.Я. Горбачевського МОЗ України»; тел. роб.: +38(063)-715-64-01. 